\title{
THE ROLE OF SCALED MODELS AND COMPUTER SIMULATIONS IN ARCHITECTURAL EDUCATION ${ }^{1}$
}

\section{ÖLÇEKLİ MODEL VE BİLGISSAYAR SIMMÜLASYONLARININ MIMMARLIK EĞITTIMINDEKİ ROLÜ}

\author{
Cengiz ÖZMEN ${ }^{1}$, Ceren KATIPOĞLU ${ }^{2}$ \\ ${ }^{1}$ Çankaya University, PhD- METU/Ankara \\ ${ }^{2}$ Attlim University, PhD-METU/Ankara
}

Öz: Bu çalış̧ma Çankaya Üniversitesi Mimarlık Bölümü’nde sürdürülmekte olan Yapısal Sistemler ve Mimarlık Tarihi derslerinde kullanılan pedagojik yaklaşmların ve eăitin teknolojilerinin semiyoloji-göstergebilim kavramları açısından yapılmış bir analizin içermektedir. Calıșmanın sorduğu soru șu șekilde özetlenebilir: eğer gercekte var olan veya tasarlanan bir yapının öğrencinin zihninde olușturduğu imge "gösterilen" olarak kabul edilirse acaba bu yapının ders ortamında gösterilen görüntü, çizim, model, simülasyon ve hesapları da "gösteren" olarak kabul edilebilir mi? Bu gösterilen ve gösteren çifti bir ișaret olușturabilir mi? Olușan bu ișaret yapının gerçekliğiyle ne kadar yakındır? Yapısal Sistemler derslerinde geleneksel olarak evrensel olarak geçerliliği kesin olarak kabul edilen matematiksel ve fiziksel prensiplerden başlayarak strüktürel açıdan sağlam bir yapıya ulaşma amacı güden bir tümevarım yöntemi uygulanmaktadır. Mimarlık Tarih derslerinde ise mevcut veya bir zamanlar var olmuş bir yapı veya yapilar grubunun inşa edildiği günden günümüze içinde var olduğu tarihi ve kültürel bağlamı da göz onüne alarak bu eserler hakkında doğru olması kuvvetle muhtemel yarglara ulassmay amaçlayan bir tümdengelim yöntemi uygulanır. Yöntemleri ne olursa olsun iki ders grubu da istenirse tek yonlü didaktik bir metot ile ogrenciye aktarlabilir. Ancak literatürdek çalıșmaların da gosterdiği gibi mimarlık ogrencileri görsel ve deneyimsel oğrenme süreçlerine daha yatkındır. Bu nedenle hem Yapısal Sistemler hem de Mimarlık Tarihi ders süreçleri görüntü, çizim, model ve simülasyonları içeren bir formatla işlenmektedir. Bu sayede olușturulan ișaretler vastassyla ogrencilerin zihnindeki imgelerin gerçek olgularla mümkün olduğu kadar benzerlik gossterir seviyeye ulaștırlması hedeflenmektedir. Yapısal Sistemler derslerinde ilk aşamada verilen teorik bilgilerin öğrenciye aktarımı mühendislik disiplinlerinin genel kabul görmüș sembol ve grafik dili ile yapılmaktadir. Bir ikon simge veya gorüntüsel gôsterge alfabesi üzerine inşa edilmiş bu sistem bahsedilen kavramlarla ilgili öğrencinin zihnindeki imgeleri dikkate almadığından gösteren-gösterilen ikilisin oluşturnakta zorlanmakta ve ekkin bir işaret yaratamamaktadir. ikinci aşamada kullanılan sayısal simülasyonlar mimarlık okullarında strüktürel tasarım derslerinde sıklıkla başvurulan temel araçlardandır. Uygulamalı tasarım projesi ile kıyaslandığı zaman model ve simülasyonlar çok daha az zamanda tamamlanan, maliyetsiz, sııırlı etkileşimli ve çoğunlukla öğrenciler tarafindan 'eğlenceli' ödevler olarak tanımlanmaktadır. Bu araç sunduğu sezgisel gerçeklik daha etkin bir işaret mekanizması kurmaktadır. Ancak simülasyonun başarısı yazılımın algoritmasının gerçekliği temsil niteliğiyle sınırlıdır Ölçekli fonksiyonel modeller ögrencinin en fazla duyusuna hitap eden uygulama türù olması nedeniyle en etkin işaret mekanizmasııı oluşturmaktadır. Yetersiz kaldığı alan ise hem yapısal davranıș dogru gösterebilecek modelin boyut ve malzeme kısıtlamalar hem de zanan ve maliyet kistlan nedeniyle sinith kullanim alani bulmasidir. Mimarlik Tarihi dersleri ilk aşamadan itibaren ikonik anlatım şekillerini kullanmaktadır. Yapısal Sistemler derslerinin aksine sembolik bir alfabeye sahip olmayan ve henüz simülasyon teknolojisinin uygulamaya geçmediği bir alan olmasının eksikliğini daha etkin bir görsel anlatım ve alan gezileriyle kapatmaktadir. Mimarlık Tarhi derslerinin konusu olan yapilar çoğu zaman görüntü ve çizimlere dayanan ikon simgeler vasitasıyla belgelendiğinden bu derslerin yararlanabileceği geniş bir literatür oluşmuş durumdadır. Buna ek olarak Mimarlık Tarihi dersleri yapıların temsilinde kullanılan ikon simgelerin zaman içerisindek gelişim ve evrimine ışık tutmaktadır. Sonuçta varılan noktada mimarlık egitiminin farkl alanlanndaki iki ders grubunun da vurgulamak istedikleri konulann etkin iletişimin gerçekleștirmek için birbirlerine benzer işaret oluşturma teknikleri olușturdukları gõzbir arada kullanıldıklarında etkin bir eğitim stratejisi oluşturabilmektedir.

Anahtar Kelimeler: Mimarlık Eğitimi, Ölçekli Modellerin rolü, Mimarılıta Simulasyon, Yapısal (Stürktürel Tasarım) Eğitimi

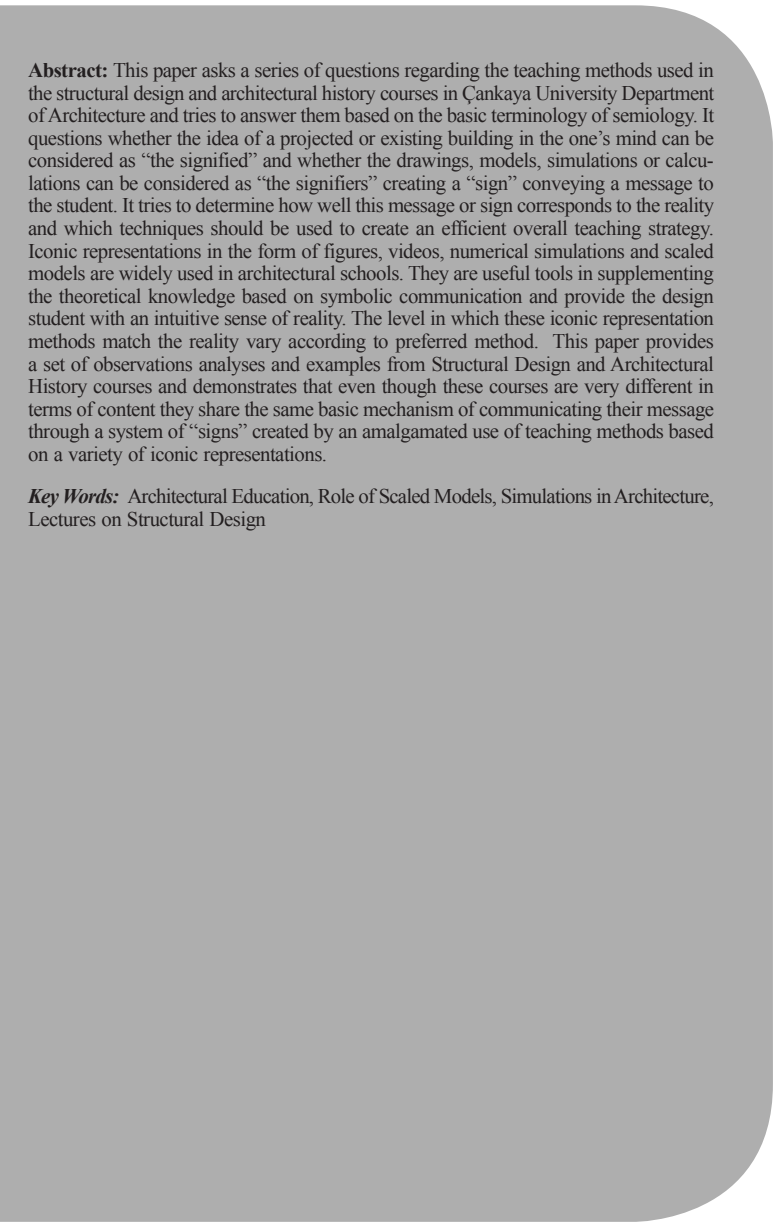

Doi: 10.17365/TMD.201549620

(1) Sorumlu Yazar: Cengiz ÖZMEN, Çankaya University,PhD-METU/Ankara cengizozmen@cankaya.edu.tr Geliş Tarihi / Received: 21.12.2014 Kabul Tarihi/ Accepted: 23.02.2015 Makalenin Türü: Type ofarticle (Araşturma Uygulama / Research -Application) Çıkar Çatışması / Conflict of Interest:Yok / None“Etik Kurul Raporu Yok - Noneof Ethics Committee" 


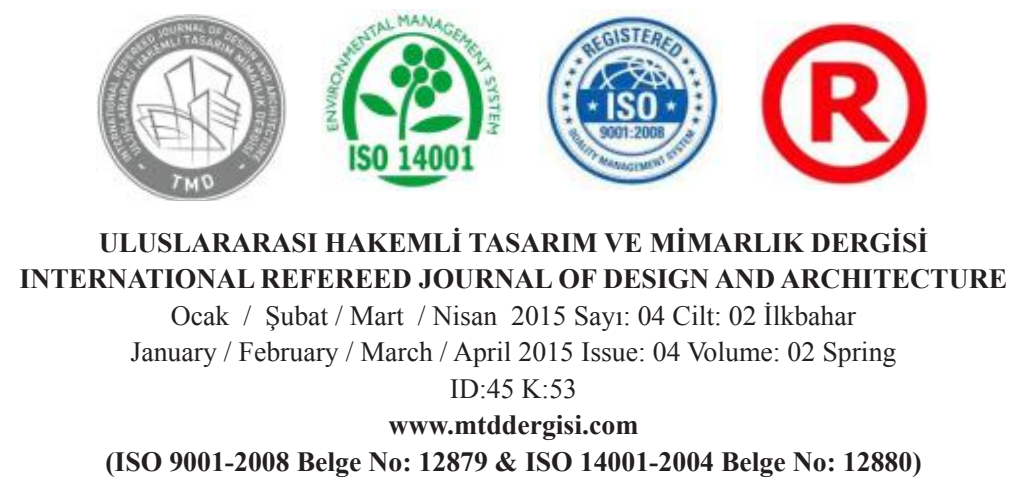

\section{INTRODUCTION}

This paper, without getting into an affected philosophical debate, asks a series of questions based on a specific set of professional experiences and the observations of its authors and tries to answer it using the basic terminology of semiology. The professional experiences mentioned here are based on an amalgamation of observations made in the structural design and architectural history courses - the respective fields of expertise of the authors- in Çankaya University and Middle East Technical University Departments of Architecture. The questions are simple: If the idea of a projected or existing building in the one's mind is considered as "the signified" then can the drawings, models, simulations or calculations be considered as "the signifiers"? If so, what is the message given by the resulting sign? Does this message or sign correspond to the reality of the building?

\section{TEACHING STRATEGIES IN STRUC- TURAL DESIGN AND ARCHITECTURAL HISTORY COURSES}

\subsection{General Principles}

In the case of structural design courses, a form of deductive reasoning is used to reach a logically certain conclusion -in the form of a statically sound structure- starting from a set of mathematical and physical principles, which are usually perceived as infallible and universally valid. On the other hand, in architectural history courses, a rather inductive approach is preferred to reach probable principles regarding the historical context of architecture starting with the qualities of an existing or documented building or group of buildings. Regardless of their methods, it is theoretically possible to teach both courses in a purely denotative format by the use of words or mathematical symbols. (Chiuini 2006) However, experiences show that, almost all the time both courses make extensive use of various visual materials, signs in the form of icons, to communicate their message and there is a good reason behind this. Studies tell us that most students of architecture are visual learners. They make use of the full array of their sensory skills as well as their analytical mind in the learning process. (Pedron 2006) Given the fact that human senses are all interconnected it is an efficient strategy, from an educational point of view, to address to as many of the sensory capabilities of the students as possible. In the case of structural design courses, this is achieved by the use of diagrams, computer simulations and small-scale models along with numerical calculations to help the students visually grasp the concept of the finished building. In the case of architectural history courses, verbal narratives are supported by drawings, photos, videos or even sounds of studied buildings to create a sense of reality, which can never be truly achieved without personally experiencing that particular piece of architecture. (Ünay and Özmen 2006) 

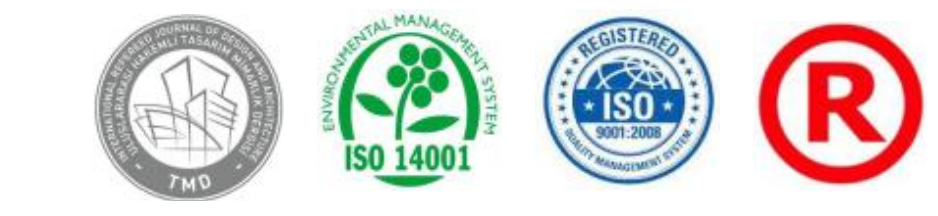

ULUSLARARASI HAKEMLİ TASARIM VE MIMARLIK DERGISI INTERNATIONAL REFEREED JOURNAL OF DESIGN AND ARCHITECTURE

Ocak / Şubat / Mart / Nisan 2015 Sayı: 04 Cilt: 02 İlkbahar

January / February / March / April 2015 Issue: 04 Volume: 02 Spring

ID:45 K:53

www.mtddergisi.com

(ISO 9001-2008 Belge No: 12879 \& ISO 14001-2004 Belge No: 12880)

\subsection{The Use of Visual Media as Icons in} Structural Design Courses

In many schools of architecture, the method of teaching in structural design courses is as follows: the students are first introduced with the theoretical basis of structural concepts, which are mostly communicated via symbolic means such as verbal descriptions and formulas. (Figure 1) At this stage, the students are mostly in a passive learning mode and they can establish little connection, if any, between the theory of scientific principles and the actual phenomenon these principles represent. (Aziz, Fahmi and Bane 2010) Form a semiological point of view there may be two reasons behind this deficiency in learning. The first is the lack of a pre-existing concept about the scientific principle-the signified-in the mind of the student; the second is the inability of the symbolic representation -the signifier- to efficiently communicate an essentially dynamic physical phenomenon. In the former case the total lack of a signified prevents the creation of a sign altogether and no message is transmitted at all while in the latter case, a sign is formed but due to the poor quality of the signifier the message is partial, amiss or incorrect. That is why additional steps are required to complete the teaching process.

\section{NEWTON'S LAW OF GRAVITATIONAL ATTRACTION:}

Shortly after formulating his three laws of motion, Newton postulated a law governing the gravitational attraction between any two particles. Stated mathematically:

$$
F=G \times \frac{m_{1} \times m_{2}}{r^{2}}
$$

Where

F = force of gravitation between the two particles

$\mathrm{G}=$ universal constant of gravitation; according to experimental evidence, $\mathrm{G}=66.73\left(10^{-12}\right) \mathrm{m}^{3} /\left(\mathrm{kg} \cdot \mathrm{s}^{2}\right)$

$\mathrm{m}_{1}, \mathrm{~m}_{2}=$ mass of each of the two particles

$r=$ distance between the two particles

\section{Figure 1. Verbal and Mathematical Communication of Structural Concepts. Source: Prepa-} red for ARCH 122 Lecture by C. Özmen in 2012

In the second step, first practical application exercises are conducted in the form of analyzing and designing hypothetical structures such as a simple truss bridge. In this stage verbal communication almost disappears and leaves its place to mostly mathematical symbology the shortcomings of which were already established in the previous paragraph. (Figure 2a) Interestingly, it is at this stage that the first iconic representations appear. (Figure 2b) These are generally in the form of 


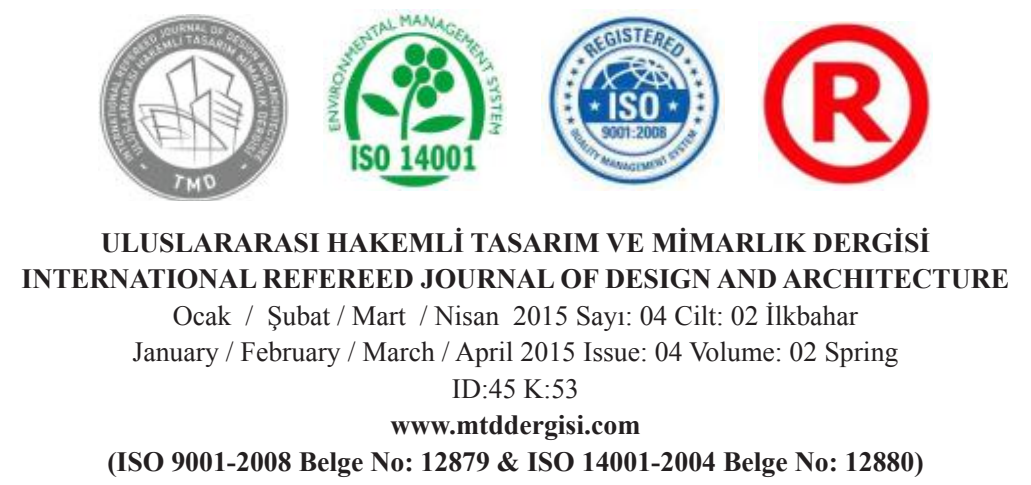

structural diagrams which are helpful in establishing a geometric awareness of the structural system. A diagram is a very simplified abstraction of an actual structure. It can be considered as an iconic signifier because it resembles the overall shape of its original and because of this visual resemblance it has a greater chance of addressing to the concept of truss-bridge -the signified- in the students mind. Unlike purely theoretical concepts such as Newton's laws of motion, there is a good chance that students have a pre-existing concept of a bridge. As a result, from the point of view of the teacher there is a greater chance of creating a viable sign for the students.

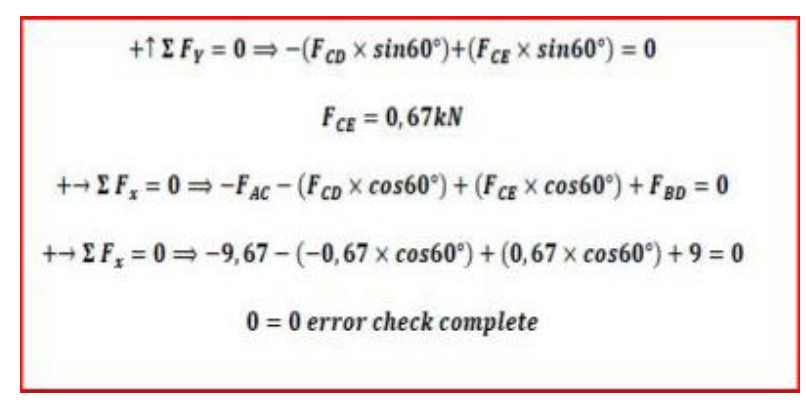

On the down side, because diagrams are very simplified and denotative representations and because human experience is very personal and very diversified it is a very low possibility that they will effectively coincide with the connotations of truss-bridge in each students mind. (Figure 3) Additionally because icons are small generic representations they can never convey the full sensory set of experiences that goes along with the "signified" image of truss-bridge. In short, structural diagrams are nothing more than simple single purpose devices which serve as a visual companion to symbologic mathematical representations.

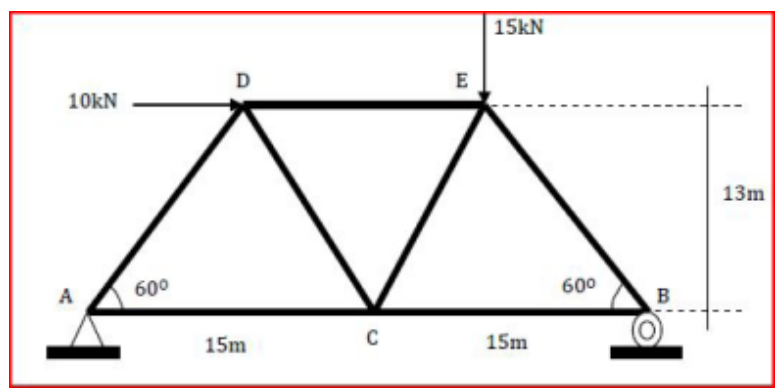

Figure 2.a \& 2.b Iconic and Symbolic Communication of Structural Concepts. Source: Prepared for ARCH 122 Lecture by C. Özmen in 2012 

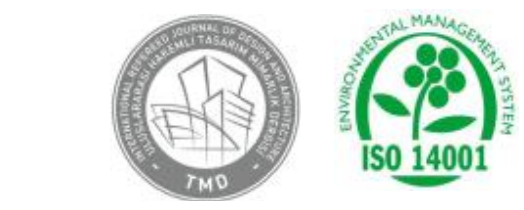

ISO 14001
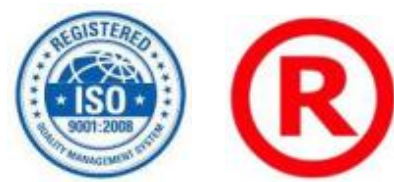

ULUSLARARASI HAKEMLİ TASARIM VE MIMARLIK DERGISI

INTERNATIONAL REFEREED JOURNAL OF DESIGN AND ARCHITECTURE

Ocak / Şubat / Mart / Nisan 2015 Sayı: 04 Cilt: 02 İlkbahar

January / February / March / April 2015 Issue: 04 Volume: 02 Spring

ID:45 K:53

www.mtddergisi.com

(ISO 9001-2008 Belge No: 12879 \& ISO 14001-2004 Belge No: 12880)

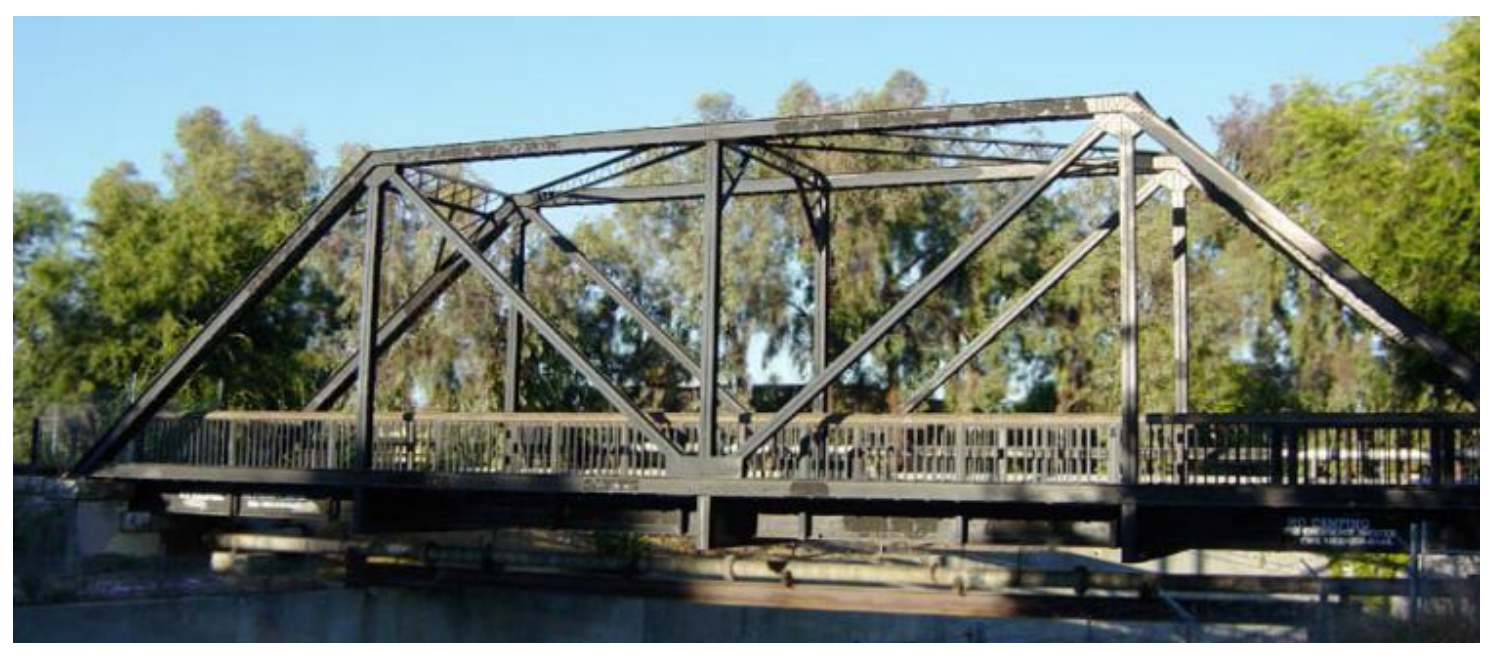

Figure 3. Varieties of Truss-Bridges May Be the Basis For "Signified" the Truss-Bridge. Source: Leonard 2012, Retrieved on 12/12/2014, Released to Public Domain 19:49 PST 15

\section{January 2012}

It is important here to note that, unlike architects who draw everything, it is possible for a competent engineer to design a structure via mathematical calculations and making use of a minimal number of iconic representations. In fact this was the method used until the last decades of the $20^{\text {th }}$ century. Yet today it is observed that several structural design software have interfaces, which provide realistic visualization and simulation of projected buildings. (Figure 4) These models are the principle tools of the third step of structural education where symbolic representations leave their place to an almost entirely iconic one.
(Vassigh 2005) Virtual models are iconic tools in the sense that they "seem to be" partial or total facsimiles of their originals but in fact they are not. Their real appearance is deceiving. They are nothing more than a visual interface of the symbolic representations of previous steps. The representational capacity of structural design software is limited with the abilities of their programmers or users to mathematically define the parameters of reality. Yet it is undeniable that the three-dimensional character of virtual models or the four-dimensional nature of simulations creates better signifiers in the minds of the students. 

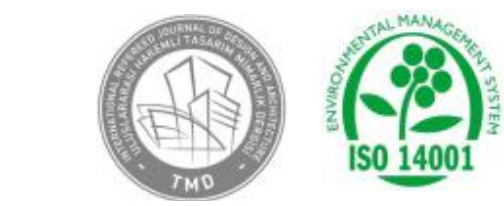

ISO 14001
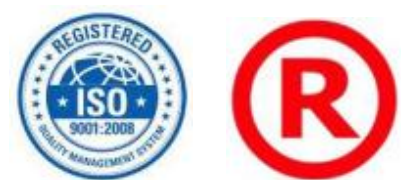

ULUSLARARASI HAKEMLI TASARIM VE MIMARLIK DERGISİ INTERNATIONAL REFEREED JOURNAL OF DESIGN AND ARCHITECTURE

Ocak / Şubat / Mart / Nisan 2015 Sayı: 04 Cilt: 02 İlkbahar

January / February / March / April 2015 Issue: 04 Volume: 02 Spring

ID:45 K:53

www.mtddergisi.com

(ISO 9001-2008 Belge No: 12879 \& ISO 14001-2004 Belge No: 12880)
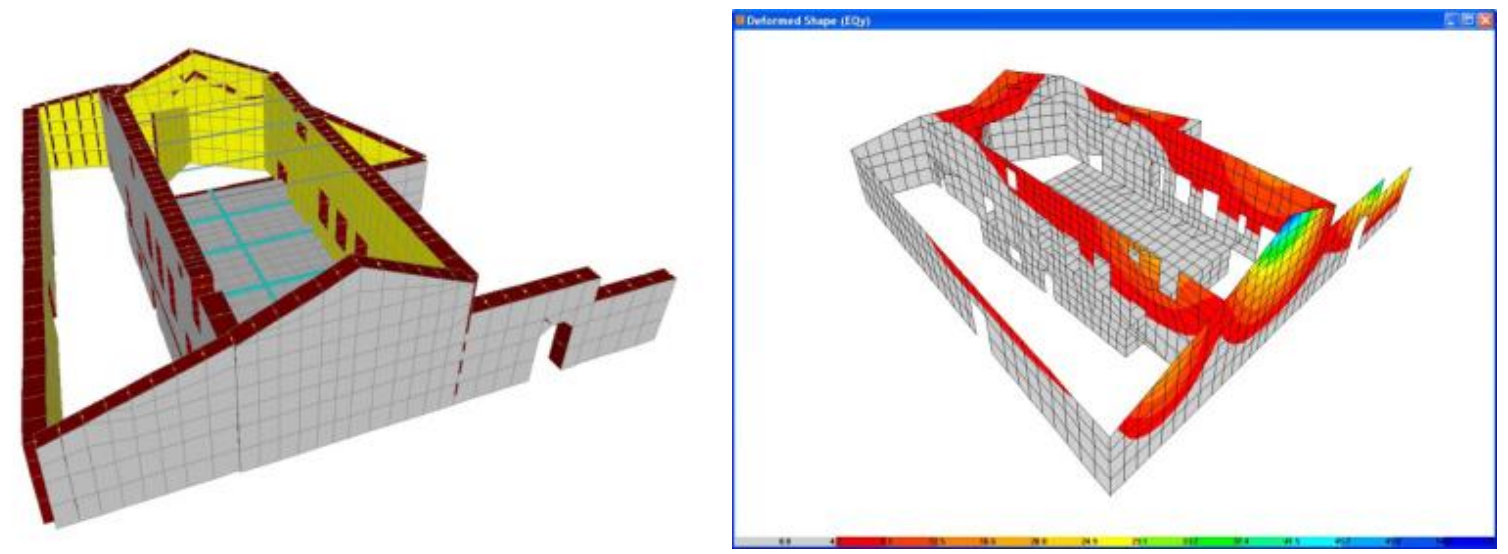

Figure 4. Two İmages From the User Interface of SAP2000 Software. Source Ünay and Özmen 2011
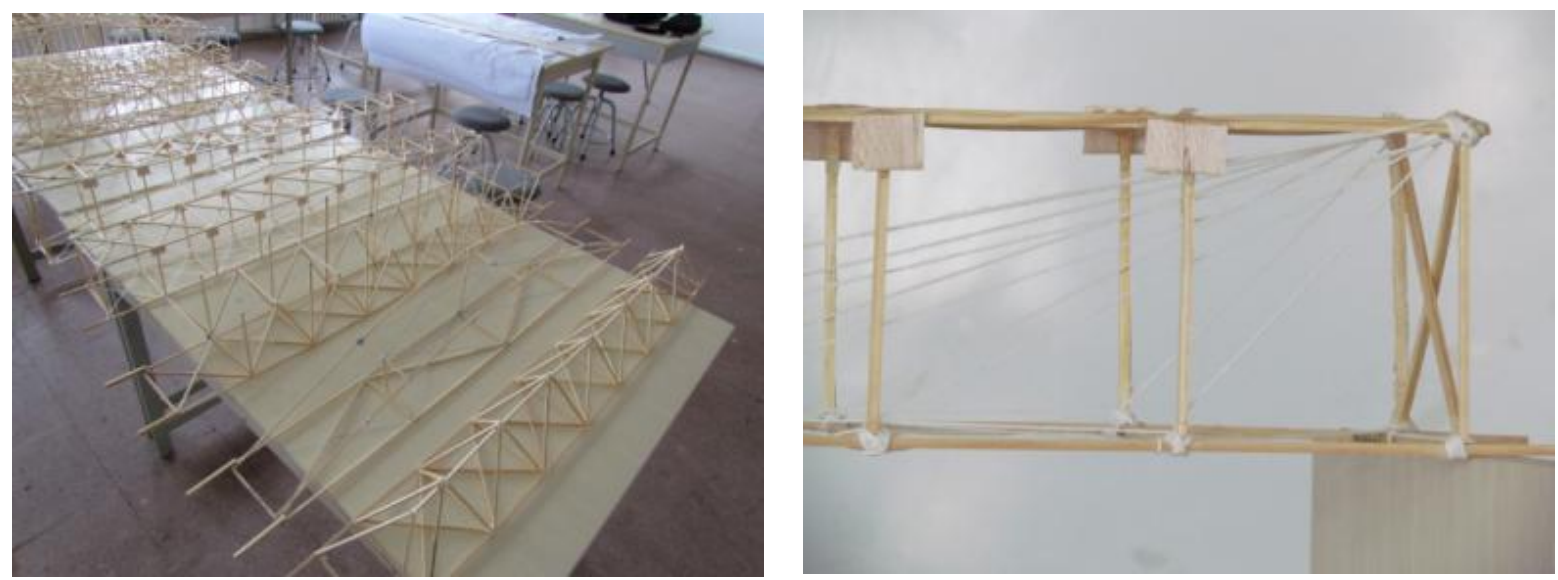

Figure 5. Small-Scale Structural Models of Truss Bridges. Source: Modeled During Arch 238 Lecture Given by C. Özmen in 2013

The last step of structural education is the building of small-scale structural models. (Figure 5) The models are subsequently loaded with weights until their ultimate crushing point to observe collapse mechanisms. Additionally the experiments are video recorded and studied in depth during the courses. In this step, several senses are used in experiencing structural behavior. If the selection of materials, detailing and loading is done appropriately, the observed results can be considered quite realistic. Here, the very existence of the model creates a dichotomy. In previous steps, the signified-signifier couple was created by the image of the bridge in students' 


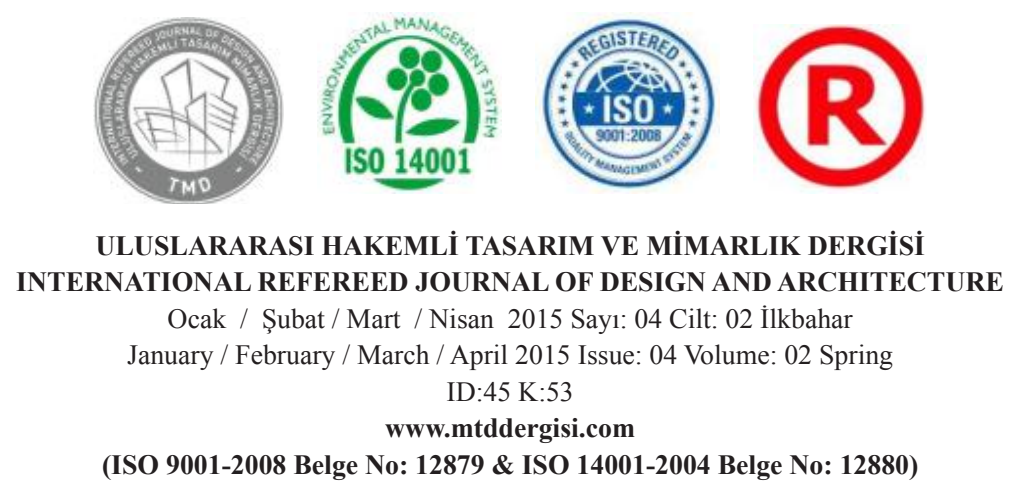

minds and the symbolic and iconic representations used during the courses. In contrast with a virtual model, a scaled model has real material substance. It is not a mere small version of an actual bridge but an object in its own right. Its structural behavior is similar to a real bridge but it has peculiar characteristics of its own. As a result, it is questionable to consider a small-scale model as a simple iconic representation. There is a chance that the use of scaled models creates additional connotations to the pre-existing mental concept of a bridge. It is on the other hand an effective means of achieving a degree of reality that cannot be provided by virtual simulations.

\subsection{The Use of Visual Media as Icons in Arc- hitectural History Courses}

In contrast with structural design courses, where there is a gradual passage from the symbolic representation towards the iconic, in architectural history courses there is a combined use verbal and visual elements from the beginning. There are two reasons for this approach. Firstly, the subject of architectural history courses, such as a famous mosque, either already exists or is well documented. As a result, there is an abundance of iconic representations in various formats. (Figure 6a) Secondly; it is obvious that describing an architectural masterpiece solely by verbal means would communicate very little to a first time learner. (Figure 6b)
Architectural History courses are interesting in the sense that they give a historical perspective of the iconic representations of architecture. Architectural students of the $21^{\text {st }}$ century are equipped with a wide variety of visual representation techniques and often take these tools for granted. They assume that these techniques have suddenly emerged in their fully developed form in the modern age. The primary objective of architectural history courses is to tell the story of architecture however, as a useful byproduct of this narrative, they also offer a glimpse to the development of architectural representation techniques. These techniques may come in the form of miniatures, primitive orthographic drawings, paintings or even scaled models. (Figure 7)

Returning to the discussion of realness, one can argue that the major part of architectural awareness comes from the act of experiencing it in other words being in contact with the reality of it. In this sense, architectural history courses attempt an impossible task: that of making the students mentally grasp thousands of years of architecture while sitting in a classroom, lacking the direct communication between its subject and its audience. As a result, they resort to the use of representations whether iconic or symbolic. There is a conscious effort to compensate for the lack of actual experience through the use of images, generally in the form of photographs, which depict not the building itself but an experiential aspect of it such as the interior lighting conditions 

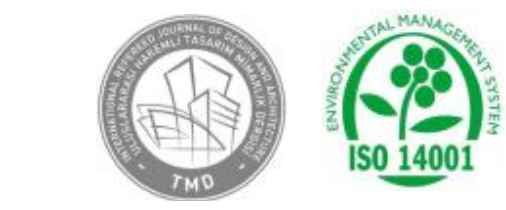

ISO 14001
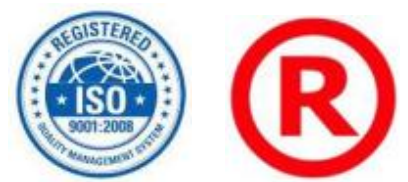

ULUSLARARASI HAKEMLİ TASARIM VE MIMARLIK DERGISİ INTERNATIONAL REFEREED JOURNAL OF DESIGN AND ARCHITECTURE

Ocak / Şubat / Mart / Nisan 2015 Sayı: 04 Cilt: 02 İlkbahar

January / February / March / April 2015 Issue: 04 Volume: 02 Spring

ID:45 K:53

www.mtddergisi.com

(ISO 9001-2008 Belge No: 12879 \& ISO 14001-2004 Belge No: 12880)

or human behavior inside the building. (Figure 8) Unlike the structural design courses where the use of iconic imagery is sequential, here it is simultaneous but towards the same objective of creating a feel of realness without actually achieving it.

\section{RELATIONSHIP BETWEEN ICONIC IMAGERY AND THE REALITY OF ARC- HITECTURE}

Having made the above argument about the use of iconic representations as signifiers of real structures or buildings, we can now try to answer the two main questions of this paper: what is the message given by the resulting sign? Does this message or sign correspond to the reality of the building?

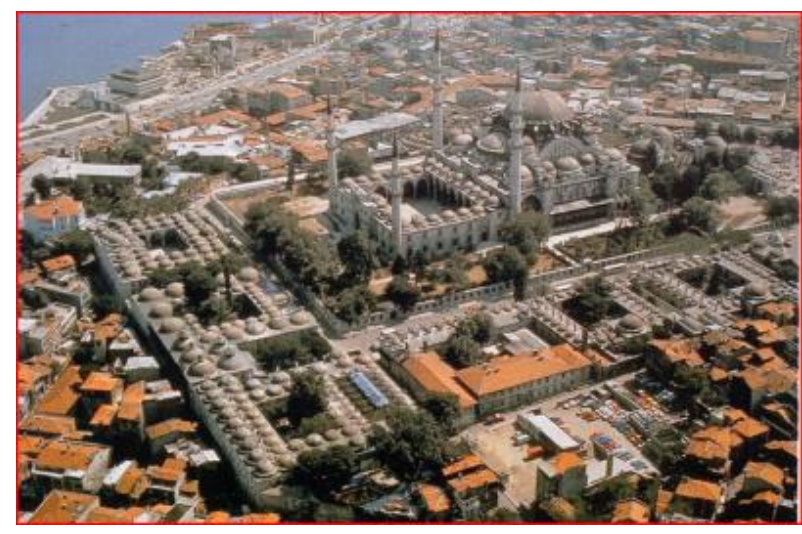

The answer to the first question probably lies in the way iconic representations are used in structural design courses. The gradual shift from symbolic representations to static iconic ones and then to animated simulations and scaled models intuitively increase the level of realness of the "learning exercise" at hand in the mind of the students. At this point, despite all verbal warnings of teachers, it is very easy to take the final mental step, maybe unconsciously, and take the scaled-model or the simulation as a facsimile of the real structure. In short, the message given by the "sign" is that of "realness". This may result in a lifelong professional misconception that the architect's ability to design a building, at least structurally, is at the level of omnipotence.

The mosque precinct contains three main areas, the mosque itself in the centre, a courtyard to the north and a tomb garden to the south which contains the tomb of Suleyman and his wife. The mosque is covered with a large central dome ( $25 \mathrm{~m}$ diameter) with two large semi-domes of equal radius, one above the north entrance and one above the mihrab. The central area is flanked by side aisles covered by small domes of alternating size. Like that of its predecessor the Sehzade Cami, the central dome rests on four huge central piers placed in a square. The whole building is illuminated with more than a hundred windows and grilles, many of which are filled with stained glass made by the celebrated Ottoman glass-maker Ibrah\&frac34;m Sarhos. Outside at each corner of the courtyard are four minarets with balconies supported on muqarnas corbels.

Figure 6.a and 6.b The Visual and Verbal Descriptions of Süleymaniye Mosque. Source: Prepared For Arch 225 Lecture Given by C. Katipoğlu in 2013 

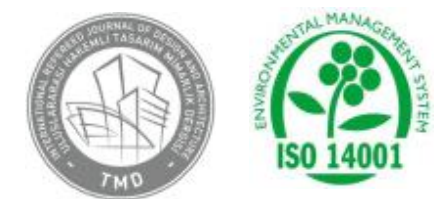

iso 14001
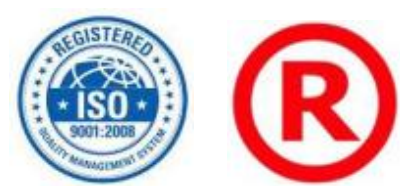

ULUSLARARASI HAKEMLİ TASARIM VE MIMARLIK DERGISI INTERNATIONAL REFEREED JOURNAL OF DESIGN AND ARCHITECTURE

Ocak / Subat / Mart / Nisan 2015 Sayı: 04 Cilt: 02 İlkbahar

January / February / March / April 2015 Issue: 04 Volume: 02 Spring ID:45 K:53

www.mtddergisi.com

(ISO 9001-2008 Belge No: 12879 \& ISO 14001-2004 Belge No: 12880)
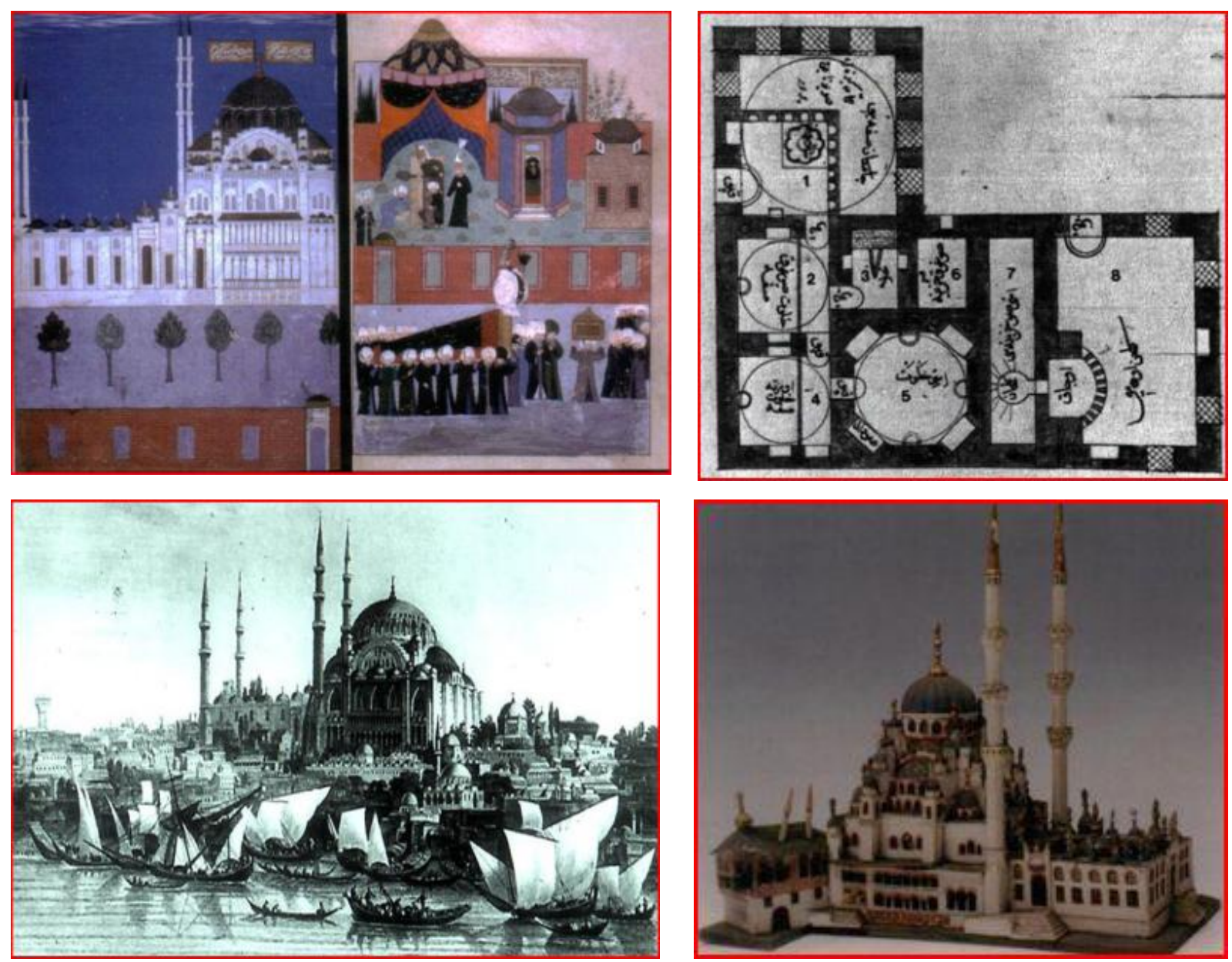

Figure 7. Various Forms of Historic Architectural Representation. Source: Necipoğlu 2005 

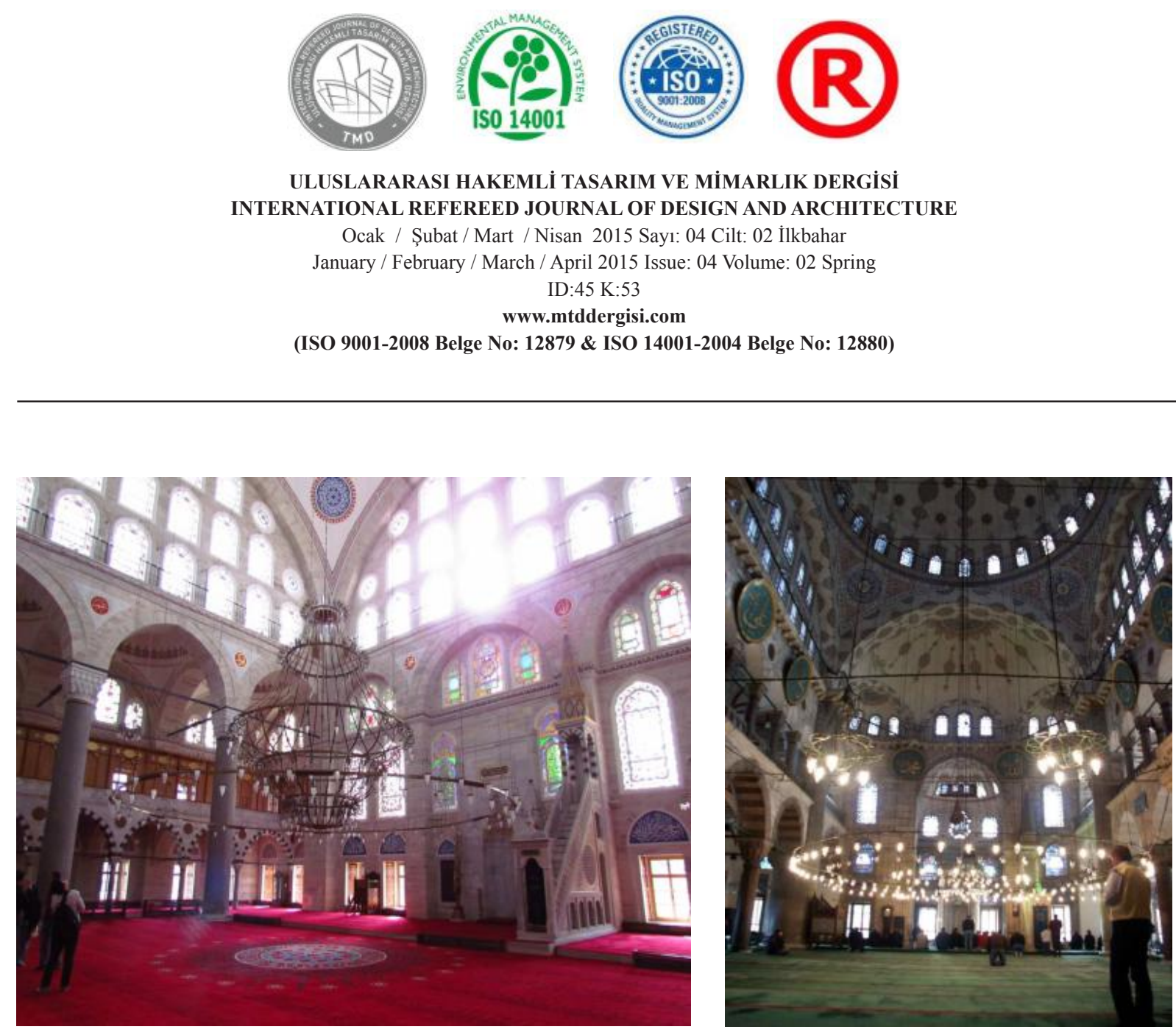

Figure 8. Natural and Artificial Lighting Conditions and Human Behavior in Two Mosques. Source: Photo by C. Katipoğlu. Prepared for Arch 225 Lecture Given by C. Katipoğlu in 2013.

This assumption of omnipotence is often misleading. Yet assigning a total deficiency of representation to simulations and models would also be farfetched. From a structural design point of view, it is possible to state that with an adequate technical understanding of the shortcomings and advantages of virtual and scaled models, it is possible to use them in the areas of application such as structural design, performance assessment or seismic retrofitting. So, we can conclude, at the risk of using non-academic vocabulary, that there is a "decent" level of realness and always a "sizeable" margin of error. From an educational point of view, the improvement of the system may be in finding better ways to communicate the parameters of the simulated environment to the students.
This brings us to answering the second question of how well the iconic representations correspond to the reality of a building from the architectural history point of view. Any iconic representation, photograph, drawing or model, can only offer a snapshot of a very large and infinitely meaningful architectural subject. Being in the format that they are, architectural history courses can at best offer a rich collection of these snapshots about any particular subject matter and hope to create a form of mental shape-collage in the minds of the students. This sign in the form of shape-collage, although able to represent the architectonic characteristics of a building to a certain degree and the personal experience of it to a lesser, is certainly not neither real nor it is trying to be. It is customary in many schools of 


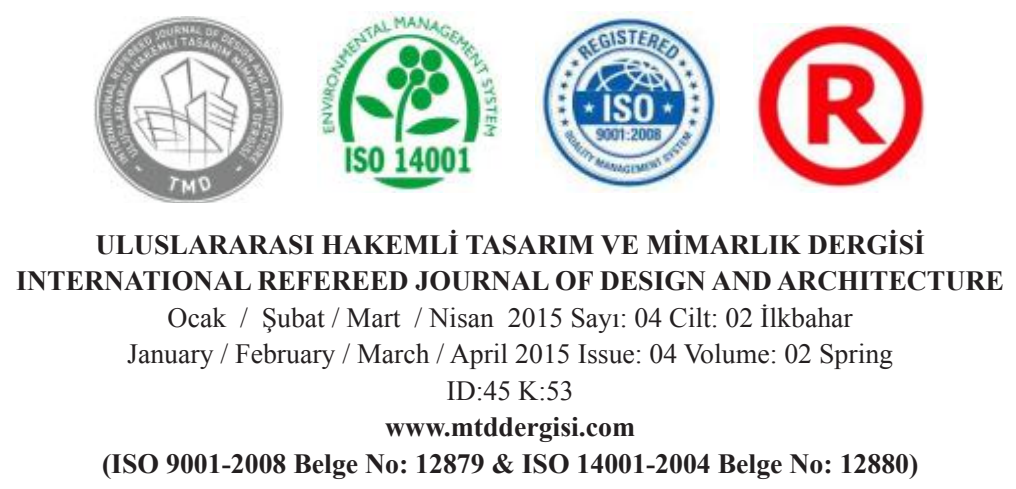

architecture to organize course trips to provide the students with the much-needed personal experience of architecture in order to augment the level of reality. It goes without saying that such trips are seriously constrained by factors such as geography, time, availability of funds, logistical capabilities, etc. In the absence of real experience, iconic representations remain as practical tools to supplement the verbal narrative of architectural history courses.

\section{REFERENCES}

AZIZ, A. A., FAHMI, M. M, BANE, T. L., (2010). "Integration of Structural Knowledge in Design Studio Project: Assessment Study of Curriculum in Architecture Course in University of Malaya" Journal of Design and Built Environment, 2010-01, ISSN: 1823-4208, Malaya

CHIUINI, M., (2006). 'Less is More: A Designoriented Approach to Teaching Structures in Architecture" Building Technology Educators Symposium, ed: Oakley, D.J., Smith, R.E., University of Maryland School of Architecture Planning and Preservation

KATIPOĞLU. C., (2013). Lecture Notes Prepared for Arch 225 Architectural History II Lecture in Çankaya University, Department of Architecture

LEONARD, G., (2012). Southern Pacific Railroad Bridge, Iron Horse Regional Trail, http://
en.wikipedia.org/wiki/File:RRTrussBridgeSideView. jpg, retrieved on 12/12/2014, Released to Public Domain 19:49 PST 15 January 2012

NECIPOĞLU, G., (2005). The Age of Sinan: Architectural Culture in the Ottoman Empire Princeton: Princeton University Press

ÖZMEN, C., (2012). Lecture Notes Prepared for Arch 122 Introduction to Engineering Mechanics Lecture in Çankaya University, Department of Architecture

ÖZMEN, C., (2012). Lecture Notes Prepared for ARCH 238 Innovative Structural Applications Lecture in Çankaya University, Department of Architecture

PEDRON, C., (2006). "Teaching the Fundamentals of Structural Analysis and Design" An Innovative Tool for Teaching Structural Analysis and Design, Institut für Baustatik und Konstruktion, ETH Zurich

ÜNAY, A. I., and ÖZMEN, C., (2006). "Building Structure Design as an Integral Part of Architecture: A Teaching Model for Students of Architecture". International Journal of Technology and Design Education, 16:253271 DOI: 10.1007/s 10798-005-5241-z, SCI-Expanded

$\ddot{U N A Y, ~ A . ~ I ., ~ a n d ~ O ̈ Z M E N, ~ C ., ~(2006) . ~ “ A s s e s s-~}$ ment of seismic resistance of Surp Nigogoyas Church under earthquake.” Structural Engi- 
ULUSLARARASI HAKEMLI TASARIM VE MIMARLIK DERGISİ INTERNATIONAL REFEREED JOURNAL OF DESIGN AND ARCHITECTURE

Ocak / Şubat / Mart / Nisan 2015 Sayı: 04 Cilt: 02 İlkbahar

January / February / March / April 2015 Issue: 04 Volume: 02 Spring

ID:45 K:53

www.mtddergisi.com

(ISO 9001-2008 Belge No: 12879 \& ISO 14001-2004 Belge No: 12880)

neers World Congress SEWC2011, Nisan

2011, Como, İtalya.

VASSIGH, S., (2005). "A Comprehensive Approach

to Teaching Structures Using Multimedia" AIA Report on University Research.http:// www.aia.org/aiaucmp/groups/ek_public/ documents/pdf/aiap080057.pdf, retrieved on $16 / 12 / 2014$ 